\title{
Clinical heterogeneity of an autoimmune disease: a case of concomitant autoimmune anaemia, autoimmune hepatitis and autoimmune bone
} marrow aplasia

\author{
Różnorodność kliniczna choroby autoimmunologicznej na przykładzie wspótistnienia \\ autoimmunologicznej niedokrwistości, autoimmunologicznego zapalenia wątroby \\ i autoimmunologicznej aplazji szpiku
}

'Students'science Club"Sferocyt," Department of Paediatrics, Haematology and Oncology, Medical University of Warsaw, Warsaw, Poland ${ }^{2}$ Department of Paediatrics, Haematology and Oncology, Medical University of Warsaw, Warsaw, Poland Correspondence: Katarzyna Pawelec, Department of Paediatrics, Haematology and Oncology, Medical University of Warsaw, Żwirki i Wigury 63a, 02-091 Warsaw, Poland, tel.: +48223179621, e-mail: katarzyna.pawelec@uckwum.pl

Abstract In autoimmune diseases, the host's immune system produces antibodies against antigens naturally occurring in its body. The immune response can be triggered by both own and foreign antigens. An important role in controlling an autoimmune process is played by genetic and environmental factors, including infections which may cause autoantibody production. The pathogenesis of autoimmune haemolytic anaemia, autoimmune hepatitis and aplastic anaemia involves autoaggressive processes. The case described in the present paper involves the coexistence of those three diseases in one patient. It is worth noting that they occur one after the other: once one of them goes into remission, another one starts manifesting itself. This study aims to draw attention to the possibility of coexistence of different autoaggressive diseases, the presence of significant correlations between them and the need to maintain vigilance with respect to patients in remission of an autoimmune disease.

Keywords: autoimmune haemolytic anaemia (AIHA), autoimmune hepatitis (AIH), aplastic anaemia (AA)

Streszczenie Choroba autoimmunologiczna to stan, w którym układ odpornościowy gospodarza wytwarza przeciwciała skierowane przeciwko antygenom naturalnie u niego występującym. Odpowiedź immunologiczna może zostać zainicjowana zarówno przez własne, jak i przez obce antygeny. Istotną rolę w kontroli procesu autoimmunologicznego odgrywają uwarunkowania genetyczne oraz czynniki środowiskowe, w tym infekcje, które mogą powodować wytwarzanie autoprzeciwciał. Niedokrwistość autoimmunohemolityczna, autoimmunologiczne zapalenie wątroby i niedokrwistość aplastyczna to jednostki chorobowe, których patogeneza obejmuje autoagresję. Na podstawie przypadku opisanego w niniejszej pracy przedstawiono występowanie tych trzech schorzeń u jednego pacjenta. Na uwagę zasługuje fakt, że następują one po sobie: kiedy pacjent uzyskuje remisję jednej z chorób, ujawnia się kolejna. Prezentowany przypadek ma na celu zwrócenie uwagi na możliwość współwystępowania różnych jednostek chorobowych z kręgu autoagresji, obecność istotnych korelacji między nimi oraz konieczność zachowania czujności w odniesieniu do pacjentów w remisji choroby autoimmunologicznej.

Słowa kluczowe: niedokrwistość autoimmunohemolityczna (NAIH), autoimmunologiczne zapalenie wątroby (AZW), niedokrwistość aplastyczna (NA) 


\section{INTRODUCTION}

$\mathrm{I}$ $\mathrm{n}$ autoimmune diseases, the host's immune system produces antibodies against antigens naturally occurring in its body, which are called autoantigens. The immune response cascade can be initiated by both own and foreign antigens. Usually both T-cells and B-cells take part in the pathogenesis of autoimmune diseases. Genetic and environmental factors, including infections which may promote the production of autoantibodies, play an important role in controlling an autoimmune process.

Autoimmune haemolytic anaemia (AIHA) is a rare disease caused by disorders of the immune system. As a result of autoantibody activity, red blood cells are excessively damaged and their lifespan is reduced ${ }^{(1)}$. In consequence, apart from signs of haemolysis, the patient develops symptoms of normocytic anaemia with a high reticulocyte count. The primary classification of autoantibodies is based on their activity in certain temperatures in vivo. There are warm antibodies, mainly IgG antibodies (type G immunoglobulins), which cause agglutination and haemolysis at $37^{\circ} \mathrm{C}$, cold antibodies, which include cold IgM agglutinins working best at $4^{\circ} \mathrm{C}$ and two-phase IgG haemolysins. Autoimmune haemolytic anaemia can develop as primary (idiopathic) anaemia accounting for at least $40 \%$ of cases in children, associated mainly with warm antibodies. It can also be secondary to autoaggressive disorders, lymphoproliferative syndromes or infections, accounting for more than half of cases in the paediatric population ${ }^{(2)}$. One of the basic serological tests used to confirm AIHA is the direct anti-globulin test (DAT); however, in approximately $10 \%$ of patients with symptoms of AIHA, no autoantibodies are found and the result of the DAT test is negative ${ }^{(3)}$.

Autoimmune hepatitis $(\mathrm{AIH})$ is a rare inflammatory disease of the liver characterised by the presence of circulating autoantibodies and an increased plasma level of gamma globulins. Disease presentation differs significantly depending on the age, race and genetic predisposition of the patient: from a completely asymptomatic disease in nearly $30 \%$ of affected individuals to acute, even fulminant liver failure. Laboratory results do not correlate with the severity of histopathological changes and the diagnosis is often determined late, at the stage of advanced liver fibrosis or cirrhosis ${ }^{(4)}$. The autoimmune nature of the disease is determined based on the presence of antibodies, usually anti-nuclear antibodies (ANA), anti-smooth muscle antibodies (anti-SMA), liver-kidney microsomal antigen 1 antibodies (anti-LKM1) and soluble liver antigen antibodies (anti-SLA) ${ }^{(5)}$. In clinical practice, AIH is often observed to co-occur with other autoimmune diseases such as thyroiditis, AIHA, glomerulonephritis, rheumatoid arthritis and ulcerative colitis.

Aplastic anaemia (AA) is a rare disorder characterised by pancytopenia and a hypocellular bone marrow without signs of regeneration ${ }^{(6)}$. The clinical presentation of the symptoms is various and is associated with cytopenia in any of the three cell lines. Haemorrhagic symptoms secondary to thrombocytopenia coexist with fatigue, pallor and cardiovascular manifestations associated with progressive anaemia. Overlapping severe bacterial and fungal infections are life-threatening to the patient and represent a therapeutic challenge. Aplastic anaemia associated with hepatitis is also a rare disease which is defined as a variant of AA. It accounts for $2-5 \%$ of all cases of AA and its symptoms are preceded by an episode of hepatitis. The disorder is more common in boys and young men ${ }^{(7)}$.

The aim of this paper is to present the case of a boy in whom three autoimmune diseases manifested themselves one after another; they were strongly correlated, ultimately leading to the boy's death.

\section{CASE REPORT}

A 12-year-old boy was admitted to a district hospital due to fever of up to $39^{\circ} \mathrm{C}$ lasting for a few days, bone and muscle pain, and increasing fatigue. On physical examination, notable findings included severe skin pallor, yellow sclerae, tachycardia and splenomegaly. The child' state on admission was rated as moderate. Laboratory tests demonstrated significantly reduced haemoglobin and red blood cell levels, normal white blood cell and platelet concentration and an elevated reticulocyte count. In addition, clinical chemistry tests showed an elevated total bilirubin level and hypertransaminasemia. On abdominal ultrasound, splenomegaly was observed (14 cm in the largest dimension). After receiving 1 unit of packed red blood cells (with no complications), the boy was transferred to the Department of Oncology and Paediatrics of the Independent Public Children's Teaching Hospital in Warsaw due to suspected autoimmune haemolytic anaemia. Upon admission, the patient's clinical condition was good and his laboratory results were observed to have slightly improved. The boy reported a decreased urine output and a dark colour of urine. On urinalysis, a slight proteinuria and traces of bilirubin were observed. Additional tests revealed elevated levels of aspartate aminotransferase (AST) (up to $200 \mathrm{U} / \mathrm{L}$ ) and lactate dehydrogenase (LDH) (up to 5,000 U/L). No antierythrocyte antibodies were found on either of two tests performed. DAT results were negative; no warm, cold or two-phase haemolysins were found either. A test for paroxysmal nocturnal haemoglobinuria, which is a characteristic feature of AIHA, was negative. A significant increase of IgM antibodies against Mycoplasma pneumoniae was confirmed, which was evidence for an atypical infection. Ceruloplasmin was not detected and thus Wilson's disease was excluded. On manual peripheral blood smear of note were significant red blood cell anisocytosis and slight rouleaux formation. Bone marrow aspiration biopsy revealed a hypercellular bone marrow with red blood cell hyperplasia (65\% of all cells) with subtle signs of dyserythropoiesis, distinct granulocyte lineage reduction and no abnormalities in other lineages. No ANA, anti-SMA, anti-LKM1 or anti-SLA antibodies were detected. During hospitalisation 
complementary packed red blood cell transfusion was performed twice. After methylprednisolone pulses were administered, red blood cell parameters improved. After 2 months the patient's condition deteriorated. On physical examination, severe skin pallor, yellow sclerae, tachycardia and hepatosplenomegaly were observed. Laboratory tests showed signs of anaemia without abnormalities in other cell lines, an elevated total bilirubin level, hypertransaminasemia and a decreased haptoglobin level. On abdominal ultrasound, significant splenomegaly (up to $17 \mathrm{~cm}$ ) and hepatomegaly were observed. A repeat serological test did not show any presence of antibodies and immune alloantibodies against red blood cells. DAT results were negative again. Due to an immunological background of anaemia a mechanism of socalled armed macrophages destroying red blood cells in the spleen was considered. A decision was made to administer pulses of methylprednisolone again, which were preceded by a packed red blood cell transfusion due to progressing anaemia. As a result of the treatment the spleen size was reduced without any effect on hepatomegaly. Blood count, and bilirubin and transaminase levels returned to normal. Due to the positive therapeutic effect of corticosteroid therapy, a decision was made to continue treatment via the oral route at $0.3 \mathrm{mg} / \mathrm{kg}$ of body mass for 3 weeks. After further 5 months of remission, when the patient developed a respiratory infection a haemolytic crisis occurred; in addition, hypertransaminasemia was found. Hepatosplenomegaly was observed on physical examination. Oral corticosteroid (prednisone) dose was increased from $9 \mathrm{mg}$ daily to $30 \mathrm{mg}$ daily and the boy was referred for further diagnostic investigation of persistent hypertransaminasemia to the Department of Gastroenterology of the Children' Memorial Health Institute in Warsaw. There, autoimmune hepatitis was finally diagnosed, which was treated with steroids and azathioprine, resulting in improvement. When the patient turned 15, due to his short stature endocrinological tests were run (glucagon stimulation test: normal pituitary response and bone age delayed by 4 years). Due to a substantial growth deficiency, growth hormone therapy was started, which was covered by private funds. As a result, the patient's growth rate improved.

When the patient was 16 years old (with AIHA diagnosis for 4 years and AIH for 2 years), during growth hormone therapy he developed fever with no clinical symptoms. On followup complete blood count $(\mathrm{CBC})$, pancytopenia was found which required further diagnostic investigation. On physical examination no enlarged lymph nodes or hepatosplenomegaly were observed. Based on aspiration biopsy and trephine biopsy (which revealed a hypocellular bone marrow with morphotic elements accounting for only a few percent of the cells present), and complete blood count severe aplastic anaemia was diagnosed ${ }^{(8)}$. A chromosome breakage test was negative (a screening test for Fanconi anaemia). Due to a lack of a family donor and a history of AIHA and AIH the patient received matched unrelated donor haematopoietic stem cell transplantation (MUD-HSCT).
The peri-transplantation period was not complicated by graft-versus-host disease (GvHD). On day 28 post transplant a hypercellular bone marrow was obtained. The boy had two episodes of cytomegalovirus (CMV) reactivation treated with intravenous ganciclovir and oral valganciclovir which led to improvement. On day 98 post transplant, at the transplant centre cell chimerism was examined: there were $85 \%$ of donor cells and $15 \%$ of recipient cells. Four months after HSCT, a follow-up CBC revealed anaemia and leukopenia with neutropenia. CMV reactivation and Epstein-Barr virus (EBV) infection were excluded based on a polymerase chain reaction (PCR) test. Despite the administration of granulocyte colony-stimulating factor (G-CSF) therapy, neutrophil count did not increase. On subsequent days, apart from pancytopenia, reticulocyte count increase and hyperbilirubinaemia were observed. Based on this, autoimmune haemolytic anaemia was suspected. Among tests performed at the Institute of Haematology and Transfusion Medicine, DAT was positive, IgG autoantibodies and complement components C3d were found on red blood cells and warm autoantibodies were detected in the serum. Bone marrow analysis revealed red blood cell hyperplasia with a significant reduction of the granulocyte, lymphocyte and megakaryocyte lineages. Since an autoimmune aetiology was suspected for the pancytopenia, a decision was made to administer methylprednisone pulses, but no improvement was achieved. Due to the presence of pancytopenia, fever and periodic rashes and considering negative blood culture tests, diagnostic investigation was started regarding parvovirus B19, adenovirus and EBV infection, and CMV reactivation. These were excluded based on negative PCR results. Despite empirical antibiotic and anti-fungal therapy, the general clinical condition of the patient was deteriorating. Multiple blood product transfusions and passive oxygen therapy were necessary. Physical examination revealed deteriorating symptoms of purpura, including subconjunctival haemorrhages; in addition, painful erythematous nodular lesions appeared on the skin of the torso and multiple rhonchi and crepitations could be heard over the lung fields (chest radiography showed interstitial densities in both lungs). Due to deteriorating respiratory function and increasing dyspnoea the boy was transferred to an intensive care unit. On subsequent peripheral blood and central line culture tests, the growth of Pseudomonas aeruginosa was obtained and sepsis caused by this bacterium was diagnosed. Despite intensive targeted antibiotic therapy, assisted respiration and complementary packed red blood cell, platelet and granulocyte transfusions, the patient's condition systematically deteriorated until the patient developed symptoms of a severe septic shock. Cardiac failure developed with an increasing tendency towards hypotension and the need to administer pressor amines. Laboratory tests revealed signs of progressive liver failure with hyperbilirubinaemia, jaundice, hypertransaminasemia and massive coagulation disturbances. Despite multiple complementary transfusions there was persistent thrombocytopenia. 
In the subcutaneous tissue erythematous nodular lesions were visible and single necrotic ischaemic lesions were present in the right foot, which are typical for Pseudomonas aeruginosa infection. Bone marrow aspiration biopsy was performed in order to evaluate haematopoiesis. Microscopy showed red blood cell hyperplasia and granulocyte and megakaryocyte aplasia. Examination of bone marrow cell chimerism demonstrated signs of graft failure. The patient died due to deteriorating symptoms of septic shock caused by Pseudomonas aeruginosa infection unresponsive to the treatment applied and progressing bone marrow aplasia.

\section{DISCUSSION}

Autoaggressive disorders are relatively rare in childhood. Their pathogenesis is not always clear and causative factors have not been defined beyond doubt yet. The case presented in this paper, which involved a disease history lasting many years, is a model example of overlapping of different autoimmune diseases. The prevalence of AIHA in children is $0.2 / 100,000$ per year, with a predominance of secondary $\mathrm{AIHA}^{(2)}$. For this reason, in the present case, the influence of CMV or Mycoplasma pneumoniae infection on the development of fully symptomatic haemolysis is suspected. Despite multiple serological tests for AIHA, no autoantibodies were detected in the patient's blood. A possible hypothesis for the pathogenesis of the disease is the mechanism of armed macrophages. Fc $\gamma \mathrm{RI}$ on macrophages bind plasma monomeric IgG whose Fab fragments may react with non-sensitised erythrocytes. A negative DAT result does not exclude AIHA: patients with DAT-negative autoimmune haemolytic anaemia account for up to as many as $10 \%$ of cases. This may be due to the presence of too low a number of IgG particles in relation to the detection threshold of standard assay methods, low affinity of IgG antibodies or the presence of anti-RBC IgA or IgM antibodies. A good therapeutic effect of corticosteroid use was observed in the patient, with periods of remission; haemolytic crises were also observed.

Autoimmune hepatitis is rare in children and is more common in girls. A characteristic feature of the disease is the presence of antibodies (ANA, anti-SMA, anti-LKM1) whose titre of 1:20 is already considered diagnostic due to the fact that they do not occur in the paediatric population in healthy individuals or those with non-autoimmune diseases $^{(5)}$. As in AIHA, in some AIH patients serological tests may not demonstrate the presence of autoantibodies circulating in the body which become detectable only after a certain duration of the disease. It is also important that other causes of liver damage are excluded such as viral hepatitis, non-alcoholic fatty liver disease, drug-induced liver damage or Wilson's disease. The majority of patients have a very good response to immunosuppressive therapy using prednisone and azathioprine. In the present patient, immunosuppressive treatment had a positive effect on symptom reduction in both AIHA and AIH. It is also worth taking note of the co-existence of these two entities which is not common despite AIH frequently co-occurring with other diseases.

The fact that the boy received growth hormone replacement therapy is also important, since growth hormone, both directly and through its mediator (insulin-growth factor, IGF-1) may stimulate the immune system or cell proliferation, thus inducing autoaggression, particularly in predisposed individuals.

Aplastic anaemia associated with hepatitis has a severe course and is not responsive to conservative treatment with anti-lymphocytic globulin and cyclosporine. The first symptoms of AA usually occur a few months after an episode of blood transaminase level increase. The development of symptoms of pancytopenia complicated with febrile neutropenia was the reason for quick investigation and diagnosis of AA. As a result of MUD-HSCT, normal bone marrow regeneration and peripheral blood appearance were obtained. At this point it is worth taking note of two episodes of CMV reactivation following bone marrow transplantation, which could have been the cause of AIHA recurrence and of the development of graft failure. Gradual progression of anaemia with reticulocytosis, a strongly positive DAT result and the presence of warm autoantibodies and laboratory signs of haemolysis raised suspicion of AIHA recurrence. Autoimmune cytopenia can appear as a rare complication of HSCT. It may be resistant to treatment and have a high mortality rate. Autoimmune haemolytic anaemia is the most common form of autoimmune cytopenia and CMV reactivation seems to be an independent risk factor for this complication. However, progressing pancytopenia with an absolute reticulocyte count falling down to 0 indicated failure of the transplanted bone marrow. Thus, overlapping symptoms were observed of two independent processes, which initially could have blurred the image and made diagnosis difficult. The occurrence of pancytopenia, fever and periodic rashes co-existing with negative peripheral blood cultures could suggest parvovirus B19 infection. By promoting direct lysis of bone marrow progenitor cells, parvovirus B19 can cause aplastic crises. Parvovirus B19 is a documented aetiological factor for AA, particularly in individuals with a history of haemolytic anaemia ${ }^{(9)}$. However, parvovirus B19 infection was excluded in the present patient. Bone marrow graft failure, which was diagnosed based on cell chimerism test, caused a lack of response to treatment, including growth factors, and finally led to the patient's death.

\section{CONCLUSION}

The case reported in this paper should draw doctors' attention to the need for thorough analysis and active search for diseases in patients with an already diagnosed autoimmune disease. The family history is often negative, as was the case in the present patient, and consecutive symptoms develop with time. 


\section{Conflict of interest}

The authors do not report any financial or personal affiliations to persons or organisations that could adversely affect the content of or claim to have rights to this publication.

\section{References}

1. Packman $\mathrm{CH}$ : The clinical pictures of autoimmune hemolytic anemia. Transfus Med Hemother 2015; 42: 317-324.

2. Adamowicz-Salach A: Niedokrwistości hemolityczne niedokrwistości autoimmunohemolityczne: od rozpoznania do leczenia. Onkol Dypl 2015; 12: 28-32.

3. Takahashi T: Direct antiglobulin test-negative autoimmune hemolytic anemia. Acta Haematol 2018; 140: 18-19.
4. Czaja AJ: Diagnosis and management of autoimmune hepatitis: current status and future directions. Gut Liver 2016; 10: 177-203.

5. Woźniak M, Woynarowski M, Socha J: Autoimmunologiczne zapalenie wątroby u trzech par rodzeństwa. Pediatr Pol 2007; 82: 463-468.

6. Hartung HD, Olson TS, Bessler M: Acquired aplastic anemia in children. Pediatr Clin North Am 2013; 60: 1311-1336.

7. Gonzalez-Casas R, Garcia-Buey L, Jones EA et al.: Systematic review: hepatitis-associated aplastic anemia - a syndrome associated with abnormal immunological function. Aliment Pharmacol Ther 2009; 30: 436-443.

8. Pawelec K: Nabyta niedokrwistość aplastyczna u dzieci - patofizjologia i czynniki wyzwalające chorobę. Klin Pediatr 2007; 15: 299-302.

9. Furukawa M, Kaji K, Masuda $\mathrm{H}$ et al.: Severe aplastic anemia following parvovirus B19-associated acute hepatitis. Case Reports Hepatol 2017; 2017: 1359486. 